ROCZNIK ADMINISTRACJI PUBLICZNEJ 2018 (4)

ARTYKUŁY Zarządzanie w administracji publicznej / Governance in Public Administration

DOI 10.4467/24497800RAP.18.012.9227

http://www.ejournals.eu/RAP/

ISSN 2449-7800 (online), ISSN 2449-7797 (druk), s. 210-218

SvetLana Drobyazko ${ }^{1}$

\title{
Personnel Management as an Element of the Company Economic Security System
}

Management of the economic security of companies is a guarantee of their successful development and one of the factors shaping the socio-economic security of the state. In modern conditions, company activity is accompanied by a constant influence of negative external and internal threats. Therefore, the effectiveness of their activities is significantly dependent on the correctness of the choice and implementation of the economic security management strategy. It is known that effective management of the economic security of the company can reduce its direct and indirect losses by $60 \%$.

As scientific works on the subject abound, it is not possible to study the wide array of points of view on the interpretation of the management of the economic security of the company given the high degree of their repeatability. The property of symmetry (asymmetry) of the company economic security should be interpreted from the standpoint of the general theory of systems ${ }^{2}$. The peculiarity of this property is that the economic security of the company can be considered symmetric and asymmetric, depending on the formative factor on which this system is built. When the formative factor is the target, the economic security of the company is asymmetric, that is, towards the target of achieving the economic security of the company it changes its characteristics. The manifestation of changing characteristics may be a change in the composition and structure of components that are bearers of characteristics. In order to achieve the ultimate desired result of its operation, the company's economic security can change the composition and structure of the components that do not affect either the target or the homeostat of the system. Otherwise, the process of reaching the target will be meaningless without changing the characteristics, the sys-

\footnotetext{
${ }^{1}$ Svetlana Drobyazko, Candidate of Economic Sciences, Assistant Professor, Professor of the Russian Academy of Natural Sciences, Professor Chair of Accounting and General Economic Disciplines, Open University of Human Development 'Ukraine'.

${ }^{2}$ Yu.A. Umantsev, General Theory of Systems in an Accessible Presentation, R \& C Dynamics, Moscow, Izhevsk 2014, passim.
} 
tem will not move from the initial phase. The situation is different when the formative factor of company economic security is a function or behavioural stereotypes. Such system must maintain the nature of its operation under all conditions. Therefore, with such systematic factors, the economic security of the company is symmetric, the set of characteristics of the system should be kept under any changes. Thus, the epistemological basis for the emergence of the theory of the security of social systems is the recognition of the existence of two basic functions in social systems: the development function and the security function. The former is associated with the pursuit of interests, which leads to the emergence of qualitatively new states of the system. The latter, in turn, is associated with actions aimed at protecting the development function from threats. As an object, it needs to use the social system as a whole and develop and improve the implementation of the function of protection of this system. Only in such a way will a balanced organisation and functioning of all components of security, such as economic, informational - or any other - be ensured.

V.F. Zhmerenetsky ${ }^{3}$ also notes the need to develop a comprehensive fundamental theory of security systems that is universal in relation to any levels and types of system security. In conclusion, the consideration of the scientific positions grouped in the third approach should be read with the scientific results of V.A. Lipkan, who warns that "the understanding of security as a system that necessarily and without alternative gives rise to stability is not entirely true and complete, because it is a consequence of the application of the determinism methodology, which is not the only possible in the study of security processes, and most importantly, it is true and productive"s.

In the course of the research, general scientific and special methods of scientific knowledge have been used, namely: critical analysis, scientific abstraction and generalisation of scientific experience of modern theoretical researches, empirical method (in determining directions of perfection of the conceptual apparatus, studying theoretical principles and scientific approaches to management of economic safety of companies); method of analysis and synthesis and theoretical generalisation (in determining scientific approaches to understanding the essence, role and place of economic security in the activities of companies).

The purpose of the work is to develop theoretical and methodological approaches and practical recommendations on the management of the personnel of the company as a component of ensuring the economic security of companies.

${ }^{3}$ V.F. Zhmerenetsky, Theory of the Security of Social Systems: A Teaching Manual, Moscow: NOU VPO MVPS 2010, pp. 177.

${ }^{4}$ V.A. Lipkan, Security Studies: Teaching Manual, European University 2003, pp. 208.

${ }^{5}$ Ibidem. 
The main objective of the economic security management system is to ensure its viability and sustainable functioning in all organisational, economic, political, social and other changes in its internal and external environment. For its achievement, the management of economic security should aim at:

- neutralisation (overcoming) or limitation of the number of negative (destructive) factors of influence on the economic security of the company through building protection against them;

- usage of positive external factors of influence for the increase and implementation of economic safety economic independence and economic security of the company, - its economic security in short;

- reproduction and incentivisation of economic safety, economic independence and economic protection of the company, i.e. its economic security, on the basis of development of its key features, market product and spatial-temporal adaptation to changes in the environment;

- assurance of the flexibility of management actions and decisions, their synchronisation with the dynamics of the negative and positive factors of economic security in a particular market.

In these conditions, from the point of view of the process approach, the management of economic security is a process of implementation of a certain set of management functions - the definition of targets, planning, organisation, motivation and control activities for the creation of economic security and livelihoods as a reason for its economic activity.

Economic security of the company is a complex and multifaceted category. Therefore, solving the problems associated with ensuring it requires companies to continuously meet the main objectives as well as improve the principles and methods of management.

The main tasks of ensuring the economic security of the company are analysis and assessment of the situation in the service market; detection of facts of unlawful negative activities of employees of the company and their elimination; constant monitoring of the state of affairs in business partners and competitors; protection of the interests of the company and the rights of its employees; possession of the necessary information for the development of optimal managerial decisions on the strategy and tactic of the company's economic activity.

At the microeconomic level, the basic principles are the following: timely prevention of possible risks; detection and prevention of internal and external threats; competitiveness; competence of employees in ensuring economic safety; the timeliness of detecting various destructive factors; rational use of material and financial resources; continuity of protection of the company's interests; consistency of action of all structural units of the company; planning; performance of company activity. 
The task of the strategic management is to ensure that the company interacts with the external environment, which will enable it to maintain the potential at a level necessary to achieve its targets and have long-term prospects. In order to determine the strategy of the company's behaviour and implement it, the management should have an in-depth understanding of the external environment, trends in its development and the place that the company occupies in it. In doing so, the external environment is studied, primarily in order to identify the threats and potential opportunities that the company must take into account when defining and achieving its targets.

The main criteria for assessing the reliability and effectiveness of the economic security of the company should be assurance of its stable operation; preservation of monetary and material values; ensuring a stable profit; prevention of crisis and emergencies; early detection, prevention and neutralisation of real and potential internal and external threats to national interests in tourism in order to create safe living conditions at the time of service.

As constituents of the company's economic security can be individual and structural units that operate directly at the company (internal entities) and organisations and officials outside the company (external actors), the safety of all constituents of the company's economic security combined with the business processes of the company ensure the continuity of the technology of providing services.

The management of the company's economic security is the process of implementing the functional components of economic security to prevent possible losses and achieve a maximum level of economic security now and in the future.

Activities to ensure the economic security of the company should include justification of the level of acceptable risk in making managerial decisions; development of a strategy and tactics of conducting economic activity, which will allow to minimise economic risk and provide economic security; protection of material, financial, personnel and information resources of the company from the possible negative effects of various factors and threats.

In our view, the economic security of the company must be considered not only from the point of view of the system approach, its manifestation the attributive approach, but also from the point of view of the resource. Reducing the level of the economic security of the enterprise is due to an insufficient qualitative and quantitative composition of resources (informational, material, labour, financial), and as a consequence, the quantitative and qualitative composition of its products (services, works). The set of company resources $\chi$ consists of elements of four subsets:

$$
\chi=\mathrm{L} \cup \mathrm{I} \cup \mathrm{F} \cup \mathrm{M}
$$


where, L - a set of labour resources; I - a set of information resources; $\mathrm{F}$ - a set of financial resources; $\mathrm{M}-\mathrm{a}$ set of marketing resources.

The company carries out the production of a set $\mathrm{Y}$ of final products (services, works). Each of the relevant resources has indicators $\left(I^{l}\right)$ that characterise the state of the system of economic security - calculated integral indicator of economic security $\left(\mathrm{I}^{\mathrm{SESC}}\right)$.

Here, there are external threats to economic security $(D)$, both potential $\left(D^{P}\right)$ and real $\left(D^{r}\right)$. The external environment should be considered as a system of the economic security of the enterprise in order to identify the mutual influence between them. After the introduction of the company's economic security management, it has plenty of management solutions (S): required () and recommended () to ensure an adequate level of the economic security of the company.

Then the economic security of the company (ESC) can be formally described as follows:

$$
S E S C=\left\{T, I_{t}^{l}, I_{t}^{S E S C}, D_{t}^{p}, D_{t}^{r}, S_{t}^{n}, S_{t}^{r e c}\right\}
$$

where $\mathrm{T}$ - a set of moments of time $\mathrm{t}$; $\mathrm{I}_{t}^{l^{-}}$a set of local indicators of economic security of the resources at the moment of time t; $I_{t}^{S E S C}$ - integral index of economic security at the moment of time t; $D_{t}^{p}, D_{t}^{r}$ - a set of corresponding real and potential threats to the economic security of the company at the moment of time $t ; S_{t}^{n}$, $S_{t}^{\text {rec }}$ - sets of necessary and recommended managerial decisions to ensure an adequate level of economic security of the company at the moment of time $t$.

From the standpoint of a resource-based approach to economic security, the effectiveness of the use of all available resources, primarily staff, is affected. At the same time, personnel for ensuring economic security should be considered in five directions ${ }^{6}$. The personnel should be considered as a special, priority type of resource, which, in combination with other company resources (assets, information, knowledge, entrepreneurial skills and others) and their qualitative status allows such an administrative unit to develop and apply strategies that increase rationality and efficiency. The personnel, as a collective of manpower, are the bearers of the corresponding properties (natural, acquired and systemic) used in the working activity and adapt in the existing conditions of the company, depending on the type of economic activity. That is, it is the ability to meet the requirements of the workplace at the company, functional duties in accordance with the internal regulations, which allows to get as close as possible to achieving

\footnotetext{
${ }^{6}$ Gillorme T.V., O.K. Yelisieieva, Models of Human Resource Management of the Company: Methodological Platform and Applications: Monograph, Dnipropetrovsk: Sole Proprietor Drobiazko S.I. 2016, pp. 170; T.V. Gillorme, Strategic Forecasting in the Process of Making Managerial Decisions on Personnel Costs Formation, Kherson State University: Economic Sciences 2016, Iss. 17, Part 1, p. 127-130.
} 
the targets of the company. As the personnel are the bearer of other special resources of the company: information, knowledge, entrepreneurial skills, it is necessary to take into account the specifics of personal targets of hired personnel, temporary, external part-time employees, working owners of the company. The personnel as a social community of employees, the association of individuals in a single system (labour collective of the company) develop and operate in accordance with the synergistic effect - the effect of the amount exceeding the sum of its constituent elements. That is, an increase in the performance of the company as a result of the unification, integration of separate individuals (personalities) in a single system (labour collective) where the effect of the interaction of elements of the company system exceeds the sum of the effects of each element separately. The personnel as an open system of public relations are formed and vary under the influence of external and internal factors. In this case, this system is characterised by integrity (labour collective (integral whole) and subsystem of separate individuals (personalities)); the hierarchy of its construction (the interaction of the two subsystems: the controlling (the employer) and the controlled (labour collective and separate individuals (personalities)); structure (the process of functioning of the system is due not so much to the properties of its individual elements as the properties of the structure itself), plurality (for the description of individual elements and systems in general, it is possible to use a multitude of cybernetic, economic and mathematical models), and systemic nature (the property of the object possesses all the manifestations of the system).

Summarising all of the above, the personnel, depending on the type of the company's economic activity, must have certain personal characteristics aimed at adapting this system to the existing changing external and internal environment, especially in the context of crisis phenomena.

In the conditions of constant development of the economy and the introduction of advanced technologies, an important component of the systemic property of the personnel of companies that affects economic security is creativity. According to A. Maslow ${ }^{7}$, this property is innate as it is inherent in any person yet under the influence of external factors it may be partially or completely lost. The content of creativity can include such properties as flexibility, learning ability, originality, receptivity, and the desire to find a way out of hopeless situations. Creativity becomes relevant in modern conditions characterised by the rapid development of society, the multiplicity of activities of organisations and rigid market competition ${ }^{8}$.

From the analysis of the characteristics of company personnel, it should be concluded that they are all closely interconnected, impacting

${ }^{7}$ A.H. Maslow, Theory of Human Motivation, „Psychological Review” 1943, Vol. 50 (4), p. 370-396.

${ }^{8}$ D. Bohinia, Mental Factors in the System of Regulation of Employment and Stimulation of Labour, „Bulletin of the Khmelnitsky National University” 2009, No. 5, p. 7-9. 
one other. Natural properties of man are the basis for the formation and existence of acquired human abilities to work. Acquired socio-professional skills of a person develop under the influence of external and internal factors. In turn, system properties are a combination of natural and functional properties.

An important property of company personnel is the adaptation ability, which means the employee's ability to adapt to changes in the content and conditions of work associated with the innovative development of the company directly in the social environment as well as to improve their business and personal qualities.

Successful adaptation of employees affects the organisation's activities; in addition, well-adapted employees are more satisfied with their work and life in general. Adaptation of the personnel is also a factor in staff development in the conditions of crisis events; it allows for developing properties aimed at the efficiency of enterprises.

The dynamic development of social relations and global changes in the totality of manpower lead to the development of personnel at all its stages: the formation, usage, storage ${ }^{9}$. During the whole life, the personnel are formed under many external and internal factors.

The personnel are probably the only resource that is constantly of value, and not only for the turnover of the company but also in public life, while acquiring all the new unique properties and changing in the structure of the components. Not only material and financial resources but also internal factors of an individual, are necessary for maintaining a proper development of the personnel.

Personnel development not only allows the company to successfully solve its problems associated with the emergence of new activities, to ensure its competitiveness, but also has a positive impact on employees: the development of skills and acquisition of the latest skills and knowledge, makes them most competitive in the labour market and offers them additional opportunities for professional growth within the company.

The development of the personnel contributes to the overall intellectual development of man, expands his/her knowledge and communication skills as well as boosts one's self-confidence. The ability to develop a career and professional growth at a company is highly appreciated by employees and has a great influence on the decision-making process when employing at companies. At the same time it benefits from internal organisational development and society in general - more qualified members and higher productivity of social work at no additional cost.

In the organisation being learning, the highest value is employees, their creative development and material well-being. The policy of personnel de-

${ }^{9}$ H.R. Nyv, Dr. Deming's Space: The Principles of Building a Sustainable Business, trans. from English M. Alpina, Business Books 2015, passim. 
velopment in such organisations is focused on the development of a system of continuing professional development of employees.

For the formation of the organisation being learning, the heads are interested in continuous improvement of knowledge of employees, the use of modern methods of development, the study and application of experience of other companies, the involvement of professionals from the side.

The target of the organisation being learning are the constant processes of mastering the latest technologies, updating the products, giving them new competitive properties through the continuous process of creative self-education of employees.

In order to improve the development of the personnel of the company, it is important to take into account foreign experience, which is conditioned by the following circumstances: the current stage of development of market relations and integration processes in the world; the objective necessity of forming a real socially oriented economy; the requirement for effective use of labour potential; further improvement of the motivation of effective work activity; turning from monetarist schemes of the economy to the account of social needs and features of the person; the transition from destructive labour conduct to innovative gradual entry into the forefront of healthy competition in society.

\section{Bibliography}

Bohinia D., Mental Factors in the System of Regulation of Employment and Stimulation of Labour, „Bulletin of the Khmelnitsky National University” 2009, No. 5, p. 7-9.

Gillorme T.V., O.K. Yelisieieva, Models of Human Resource Management of the Company: Methodological Platform and Applications: Monograph, Dnipropetrovsk: Sole Proprietor Drobiazko S.I. 2016, pp. 170.

Gillorme T.V., Strategic Forecasting in the Process of Making Managerial Decisions on Personnel Costs Formation, Kherson State University: Economic Sciences 2016, Iss. 17, Part 1, p. 127-130.

Lipkan V.A., Security Studies: Teaching Manual, European University 2003, pp. 208.

Maslow A.H., Theory of Human Motivation, „Psychological Review” 1943, Vol. 50 (4), p. 370-396.

Nyv H.R., Dr. Deming's Space: The Principles of Building a Sustainable Business, trans. from English M. Alpina, Business Books 2015.

Umantsev Yu.A., General Theory of Systems in an Accessible Presentation. $R \& C$ Dynamics, Moscow Izhevsk 2014.

Zhmerenetsky V.F., Theory of the Security of Social Systems: A Teaching Manual, Moscow: NOU VPO MVPS 2010, pp. 177.

Abstract

The most important strategic directions of ensuring economic security of an enterprise is the identification, prevention, neutralisation, suppression, localisation of and 
counteracting dangers and threats, and in case of need - damage compensation and recovery of objects of protection injured by illegal actions, negligence, force-majeure circumstances, etc.

Keywords: counterparties, receivables, debt quality, matrix

\section{Zarządzanie kadrami jako element systemu bezpieczeństwa ekonomicznego przedsiębiorstwa \\ Streszczenie}

Najistotniejsze strategiczne kierunki zapewnienia bezpieczeństwa ekonomicznego przedsiębiorstwa to identyfikowanie, zapobieganie, neutralizowanie, tłumienie, lokalizowanie oraz oddalanie niebezpieczeństw i zagrożeń, a w razie konieczności - rekompensowanie szkód i odzyskiwanie przedmiotów ochrony uszkodzonych poprzez niezgodne z prawem działania, zaniedbania, okoliczności siły wyższej itd.

Słowa kluczowe: kontrahent, należności, jakość zadłużenia, macierz 